\title{
Desain E-Learning Berbasis Google classroom Pada Mata Pelajaran Al- Qur'an Hadis
}

\author{
*Ahmad Muzakki², Winarto Eka Wahyudi ${ }^{4}$ \\ 1 UIN Sunan Ampel, Surabaya, Indonesia \\ ${ }^{2}$ Universitas Islam, Lamongan, Indonesia \\ * email: zakki.f35@gmail.com (Corresponding Author)
}

\begin{tabular}{|c|c|}
\hline (A) Check for updates open access @) (i) & DOI: https://doi.org/10.53621/jider.v1i1.22 \\
\hline Informasi Artikel & ABSTRAK \\
\hline $\begin{array}{l}\text { Riwayat Artikel: } \\
\text { Diterima: } 22 \text { Agustus } 2021 \\
\text { Revisi Akhir: } 25 \text { Agustus } 2021 \\
\text { Disetujui: } 25 \text { Agustus } 2021 \\
\text { Terbit: } 25 \text { Agustus } 2021\end{array}$ & $\begin{array}{l}\text { Penelitian ini bertujuan untuk mengetahui desain pembelajaran online (E- } \\
\text { learning) berbasis Google classroom, mengetahui respon siswa terhadap } \\
\text { pembelajaran berbasis Google classroom dari paparan beberapa hasil } \\
\text { penelitian yang pernah dilakukan. Penelitian ini menggunakan metode } \\
\text { kajian pustaka, dengan cara menghimpun hasil penetian terdahulu yang }\end{array}$ \\
\hline $\begin{array}{l}\text { Kata Kunci: } \\
\text { E-learning, } \\
\text { Google classroom, } \\
\text { Pembelajaran, } \\
\text { Al-Qur'an Hadits, }\end{array}$ & $\begin{array}{l}\text { sesuai dengan tema E-learning berbasis Google classroom. Hasil temuan dari } \\
\text { beberapa literature review menunjukkan pelaksanaan E-learning berbasis } \\
\text { google classroom, pada hasil pembelajaran mengalami peningkatan } \\
\text { ketuntasan dari } 70,94 \% \text { meningkat jadi } 88.88 \% \text {. dari paparan diatas, dapat } \\
\text { disimpulkan bahwa E-learning berbasis Google classroom bisa jadi solusi }\end{array}$ \\
\hline 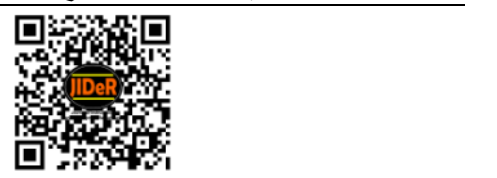 & $\begin{array}{l}\text { pelaksanaan pembelajaran pada mata pelajaran Al-Qur'an Hadits. Akan } \\
\text { tetapi perlunya sosialisasi terhadap guru dan siswa, mengingat tidak sedikit } \\
\text { guru dan siswa yang masih awam dengan penggunaan platform Google } \\
\text { classroom tersebut. }\end{array}$ \\
\hline
\end{tabular}

\section{PENDAHULUAN}

Al-Qur'an hadits merupakan bagian dari mata pelajaran agama Islam yang bertujuan untuk membentuk kepribadian dan prilaku yang sesuai dengan ajaran Islam dan mewujudkan nilai moral dan agama berdasarkan dengan tujuan pendidikan nasional. Dengan didukung guru yang kompeten serta sarana prasarana yang mendukung untuk proses pembelajaran, maka dapat meningkatkan hasil dan capaian tujuan pembelajaran Al-Qur'an Hadits (Niken Septantiningtyas, 2019).

Era digitalisasi seperti saat ini, teknologi informasi yang terus berkembang, guru dituntut untuk lebih inovatif dan kreatif dalam mengikuti perkembangan zaman. Pendidikan berbasis elearning menjadi alternatif di era digital seperti saat ini. Kemajuan teknologi informasi sangat mempengaruhi dunia pendidikan, sistem pendidikan yang lebih terbuka dan fleksibel yang tidak terbatas ruang dan waktu. Pengaruh positif dari kemajuan tekonologi informasi bagi pendidikan adalah sistem pendidikan yang lebih terbuka, siswa tidak harus datang ke sekolah, materi bisa diakses kapan saja dan dimana saja. Ini sangat membantu terutama bagi siswa yang mempunyai kendala belajar secara tatap muka, misalnya siswa yang jarak rumahnya sangat jauh dari sekolah. E-learning menjadi solusi pembelajaran jarak jauh yakni kemudahan dalam mengakses pendidikan serta meningkatkan hasil pembelajaran (Budi Santoso, 2020). Maka guru dituntut untuk lebih kreatif dalam melakukan pembelajaran, terutama pembelajaran jarak jauh. Karena kreatifitas merupakan hal yang harus dipenuhi oleh guru, karena guru saat ini jauh lebih berkembang, berbeda dengan guru pada zaman dulu (Humaidi \& Sain, 2020). Ada banyak platform berupa kelas virtual yang dapat dimanfaatkan oleh guru dalam melakukan pembelajaran jarak jauh, seperti: google classroom, etmodo dan schoology (Dwining Bintarawati, 2020).

Salah satu platform e-learning yang popular digunakan adalah Google classroom. Google classroom adalah salah satu platform E-learning yang membantu siswa dan guru dalam 
melakukan pembelajaran, modelnya seperti kelas, akan tetapi berbasis virtual. Google classroom dirancang untuk memudahkan interaksi antara guru dan siswa dalam dunia maya (Rozak \& Albantani, 2018).

Penggunaan E-learning berbasis Google classroom juga mempengaruhi meningkatnya motivasi belajar siswa ditengah pandemi yang saat ini melanda. Dari hasil sebuah penelitian tindakan kelas yang menerapkan pembelajaran berbasis Google classroom, dapat meningkatkan motivasi dan hasil belajar mahasiswa. Ini dibuktikan dari pelaksanaan tindakan kelas mulai dari sebelum tindakan, siklus I dan siklus II. Keberhasilan meningkatnya motivasi belajar mahasiswa ditandai dengan rata-rata $75-100 \%$. Sementara hasil yang didapat ketika tindakan siklus I sebesar $74 \%$ dan siklus II sebesar $80,11 \%$. Sementara itu juga mengalami peningkatan hasil belajar mahasiswa. Terjadinya peningkatan pada pra tindakan dari 50,75\% meningkat menjadi 73,53\%. Pada siklus I mengalami peningkatan dari 73,53 menjadi 87,35 (Daniati, Bambang Ismanto, 2020). Dari hasil penelitian tersebut, dapat disimpulkan bahwa penggunaan E-learning berbasis Google classroom dapat meningkatkan motivasi dan hasil belajar mahasiswa, yang mana juga memungkinkan diterapkan kepada siswa.

Berdasarkan penelitian yang dilakukan oleh Maskar dan Wulantina (2019) menghasilkan bahwa model pembelajaran blended learning berbasis Google classroom menjadikan pembelajaran lebih aktif, kreatif serta dapat menumbuhkan motivasi dan minat belajar secara mandiri (Maskar, 2019). Ninik Rahayu Ashadi, Sutarsih Suhaeb (2020) dalam penelitiannya pada mahasiswa PTIK tentang manfaat penggunaan Google classroom terhadap kemandirian dan hasil belajar mahasiswa, menunjukkan bahwa: pertama, adanya hubungan yang signifikan antara penggunaan Google classroom dengan hasil belajar mahasiswa, hal ini dibuktikan dengan nilai Sig. $(2$-tailed $)=0.000<0.05(5 \%)$, angka koefisien korelasi Pearson sebesar 0.569. Kedua : dengan menggunakan Google classroom dapat meningkatkan kemandirian belajar mahasiswa, hasil penelitian ini dibuktikan dengan nilai Sig. (2-tailed) $=0.029<0.05(5 \%)$ sedangkan angka koefisien korelasi Person sebesar 0.316 (Ashadii \& Suhaeb, 2020). Lebih lanjut, Dwining Bintarawati dan Yudin Citriadin (2017), pembelajaran berbasis Google classroom, menunjukkan bahwa pembelajaran berbasis kelas virtual Google classroom dapat meningkatkan klasikal ketuntasan dengan prosentase pada siklus pertama sebesar $70,94 \%$ sedangkan pada siklus kedua meningkat jadi $88,88 \%$. Sedangkan keaktifan siswa pada mata pelajaran kimia juga mengalami peningkatan dengan prosentase pada siklus pertama sebesar 92,31\% jadi 94,23\% (Dwining Bintarawati, 2020).

Sedangkan permasalahan yang saat ini dialami adalah kurangnya pemahaman guru dan siswa tentang e-learning berbasis google classroom. Padahal dengan menggunakan google classroom, menjadi peluang bagi guru dalam meningkatkan dan mengembangkan kompetensi khususnya kompetensi mengajar (Rozak \& Albantani, 2018). sedangkan ada empat kompetensi yang harus dimiliki oleh guru, salah satunya adalah kompetensi profesionalisme yakni kompetensi dalam penugasan dan pemberian materi pembelajaran yang inovatif (Niken Septantiningtyas, 2019) Oleh karena itu, dalam artikel ini penulis merancang desain kelas virtual pembelajaran e-learning berbasis google classroom pada mata pelajaran Al-Qur'an Hadits, yang diharapkan dapat meningkatkan kompetensi professional guru dalam mengembangkan pembelajaran yang terbuka dan inovatif.

\section{METODE PENELITIAN}

Penelitian artikel ini menggunakan pendekatan kualitatif, dengan metode kajian studi pustaka (literature review). Yang biasanya digunakan untuk "eksplorasi" dengan cara mengkaji hasil studi penelitian terdahulu yang relevan (Niken Septantiningtyas, 2019).

Tahapan penelitian studi pustaka ini dimulai dengan pengumpulan sumber-sumber pustaka yang relevan, dengan mengklasifikasikan sesuai dengan formula penelitian. Adapun data yang diimpun adalah informasi dan hasil penelitian terdahulu tentang penggunaan dan desain e-learning berbasis google classroom. 
Pada tahap selanjutnya adalah dengan mengolah data yang sudah dihimpun untuk proses pengutipan referensi yang ditampilkan sebagai temuan hasil penelitian terdahulu, mendapatkan informasi secara utuh dan di interpretasikan untuk penraikan kesimpulan. Setelah tahap interpretasi data, maka akan dilanjutkan dengan tahap analisis data secara deduktif, induktif, interpretative dan komprehensi, serta melakukan survey lapangan untuk melihat sejauh mana keefektifan pemanfaatan e-learning berbasis google classroom.

Dari hasil uraian diatas, dapat disimpulkan bahwa tujuan dari penulisan artikel ini adalah untuk memberikan alternatif desain e-learning berbasis google classroom pada mata pelajaran AlQur'an Hadits.

\section{HASIL DAN PEMBAHASAN}

Berdasarka hasil studi pustaka, bahwa pembelajaran e-learning dengan menggunakan media kelas virtual google classroom sangat memudahkan guru untuk melaksanakan pembelajaran secara maya, serta memudahkan guru untuk mendapatkan banyak materi dan membagikan ke seluruh siswa secara maya dengan bantuan jaringan internet. Dengan menggunakan media google classroom guru tidak perlu melakukan proses instalasi yang rumit, guru hanya membutuhkan email dari google untuk dijadikan akun google classroom. Tahapan yang harus dilakukan untuk membuat kelas virtual dengan google classroom adalah dengan cara masuk di akun google, lalu dengan mengklik google apps, kemudian pilih google classroom.

Tampilan awal halaman google, sebelum masuk di google classroom. Pada halaman ini pengguna bisa memilih menu google classroom pada halaman google apps.

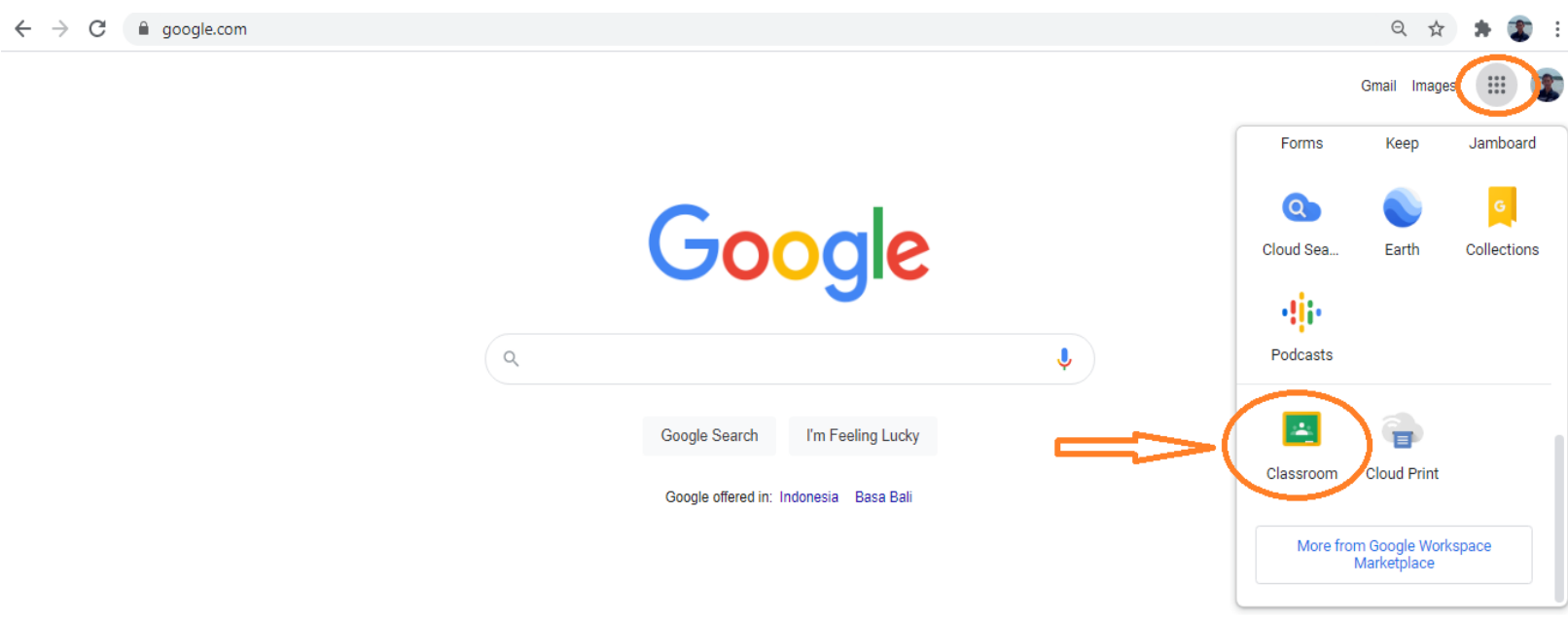

Gambar 1. Mulai Membuka google classroom

Google classroom karena berbasis web, jadi tidak membutuhkan instalasi yang rumit, juga bisa diakses menggunakan perangkat komuter dan smartphone yang terkoneksi dengan jaringan internet. Langkah selanjutnya, membuat kelas, dengan cara klik menu (tanda tambah) pada halaman berikut, seperti tampilan gambar di bawah ini. 


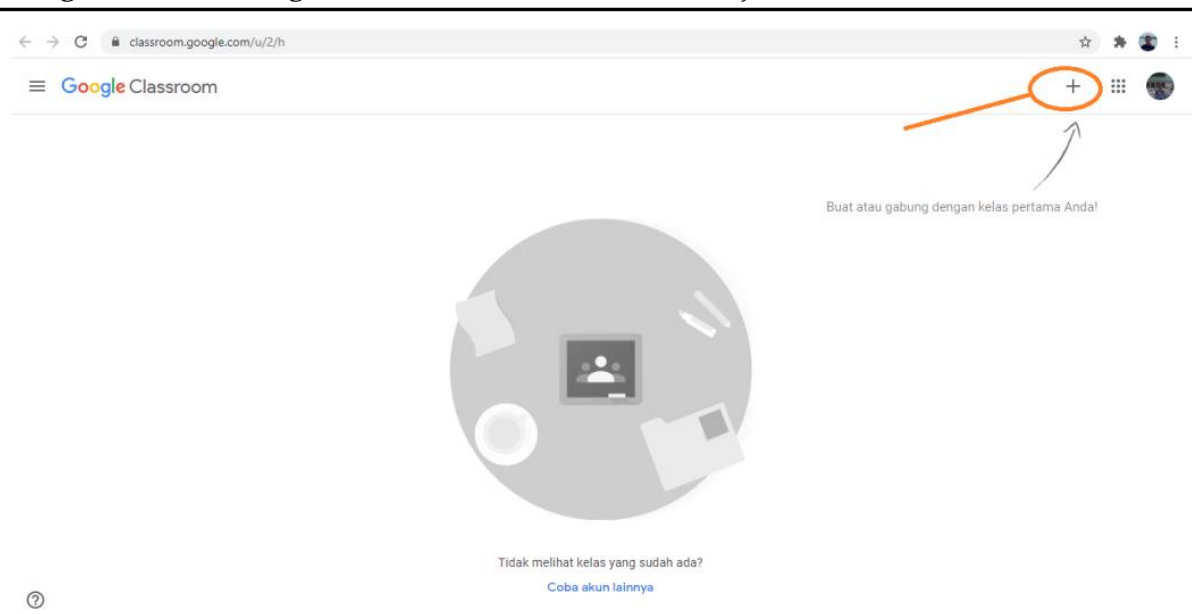

Gambar 2. Memulai Membuat Kelas

Setelah memilih menu tambah kelas, maka akan muncul halaman identitas kelas yang akan dibuat. Seperti tampilan pada gambar di bawah ini.

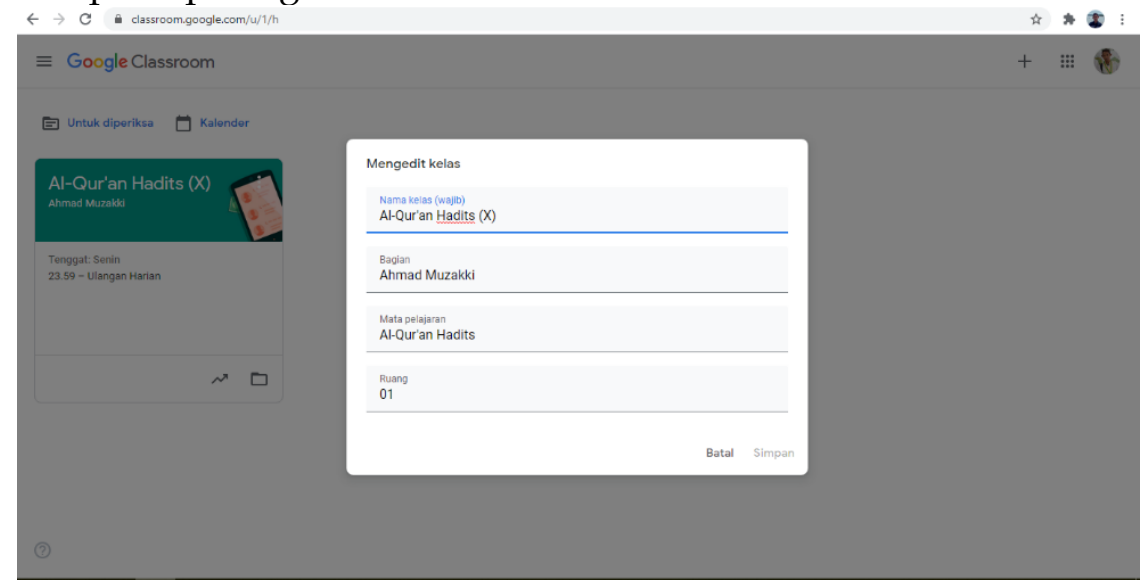

Gambar 3. Halaman Identitas Kelas

Pada tampilan diatas, terdapat empat kotak dialog, yang digunakan untuk mengisi identitas kelas yang meliputi Nama kelas, Bagian, Mata Pelajaran dank kode ruang. Selanjutnya guru bisa memasukkan siswa ke dalam kelas virtual pada google classrrom sesuai dengan kelas masing-masing.

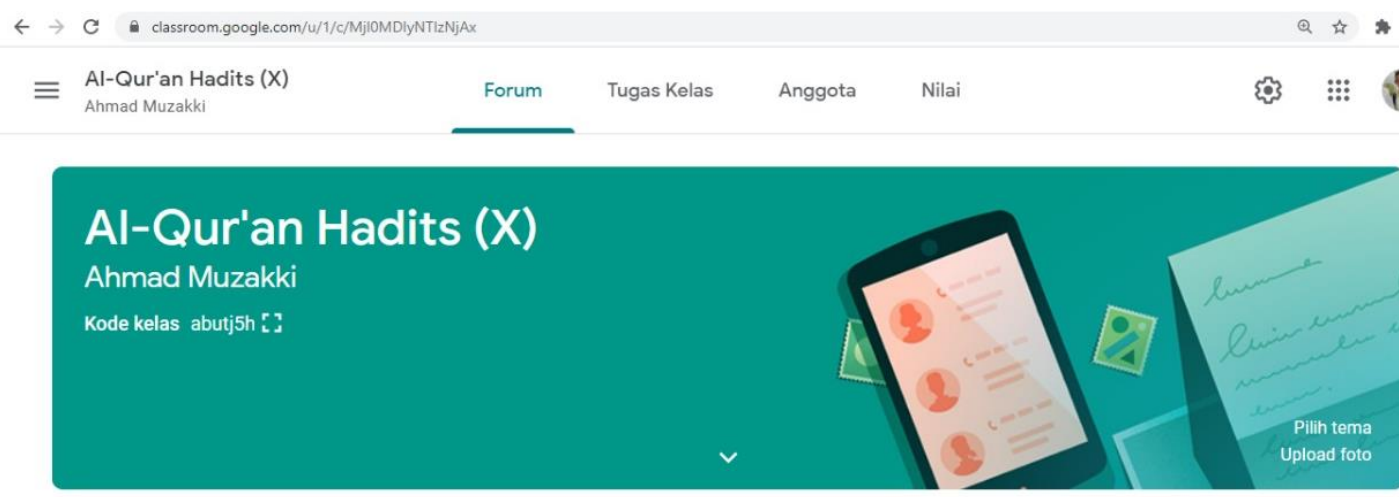

Gambar 4. Kelas Mata Pelajaran 
Adapun fitur-fitur yang terdapat pada tampilan awal kelas virtual google classroom adalah sebagi berikut:

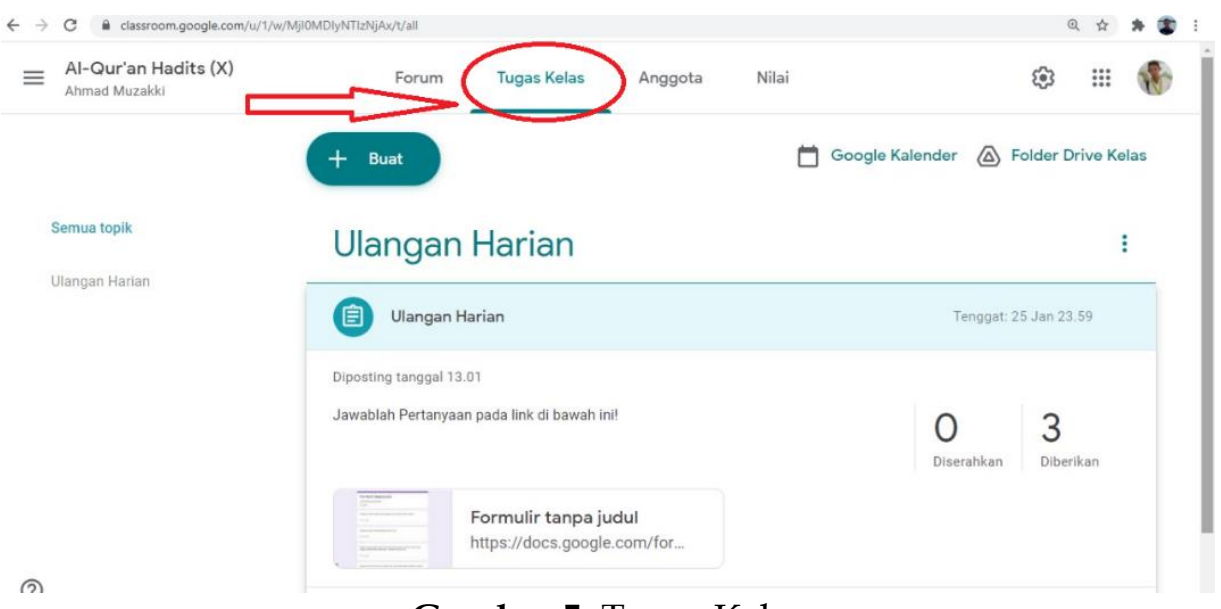

Gambar 5. Tugas Kelas

Menggunakan fitu penugasan, maka tugas siswa adapat disimpan dengan terintegerasi google drive, yang memungkinkan siswa dapat menyerahkan tugas dan guru bisa melihat, mengedit dan menilai hasil kerja siswa. Selain dengan bantuan google drive, penugasan menggunakan Google classroom juga bisa dilakukan dengan fitur google form, yakni semacam formulir yang bisa dimanfaatkan untuk media evaluasi, baik berupa pilihan ganda dan esai, yang nantinya hasil pekerjaan siswa bisa langsung otomatis terkoreksi.

Komunikasi

Fitur komunkasi ini memudahkan interaksi dua arah antara guru dan siswa. Selain guru, siswa juga bisa memposting hasil tugas di forum dan semua anggota kelas bisa menanggapi hasil pekerjaan yang diposting layaknya diskusi di kelas.

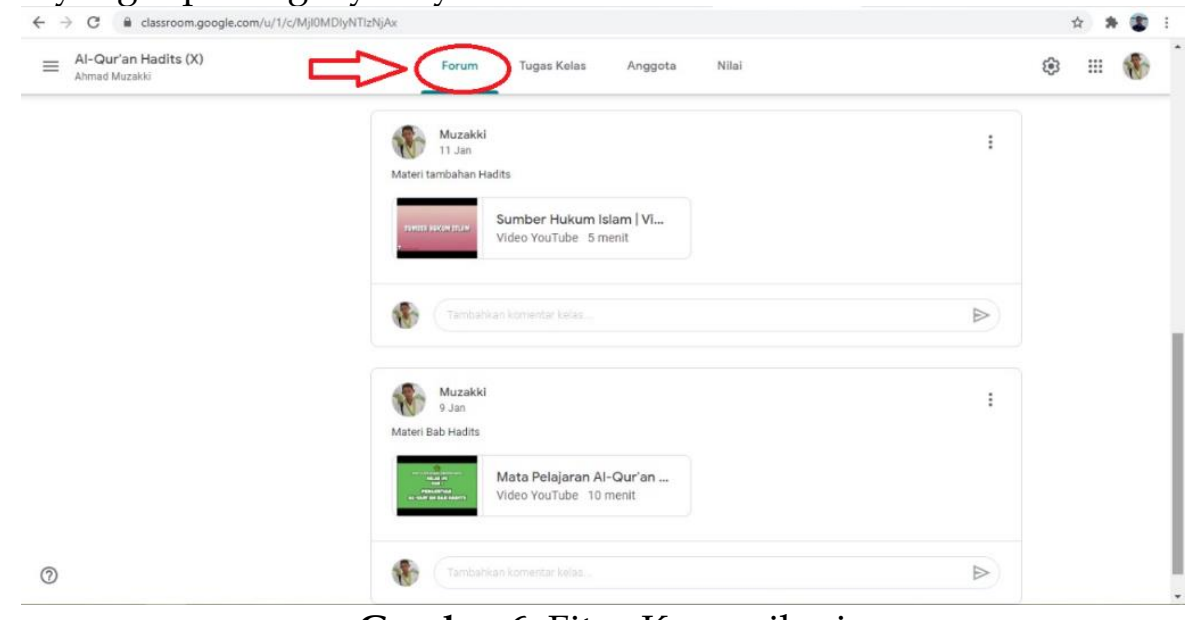

Gambar 6. Fitur Komunikasi

Google classroom memudahkan guru dalam membagi materi yang bisa berupa lampiran file video, dokumen, powerpoint, link web, youtube dan google drive. Google classroom ini mendukung perangkat berbasis windows (komouter dan laptop), juga berbasis android dan IOS yang digunakan dalam smartphone. Seperti pada tampilan halaman di bawah ini. 


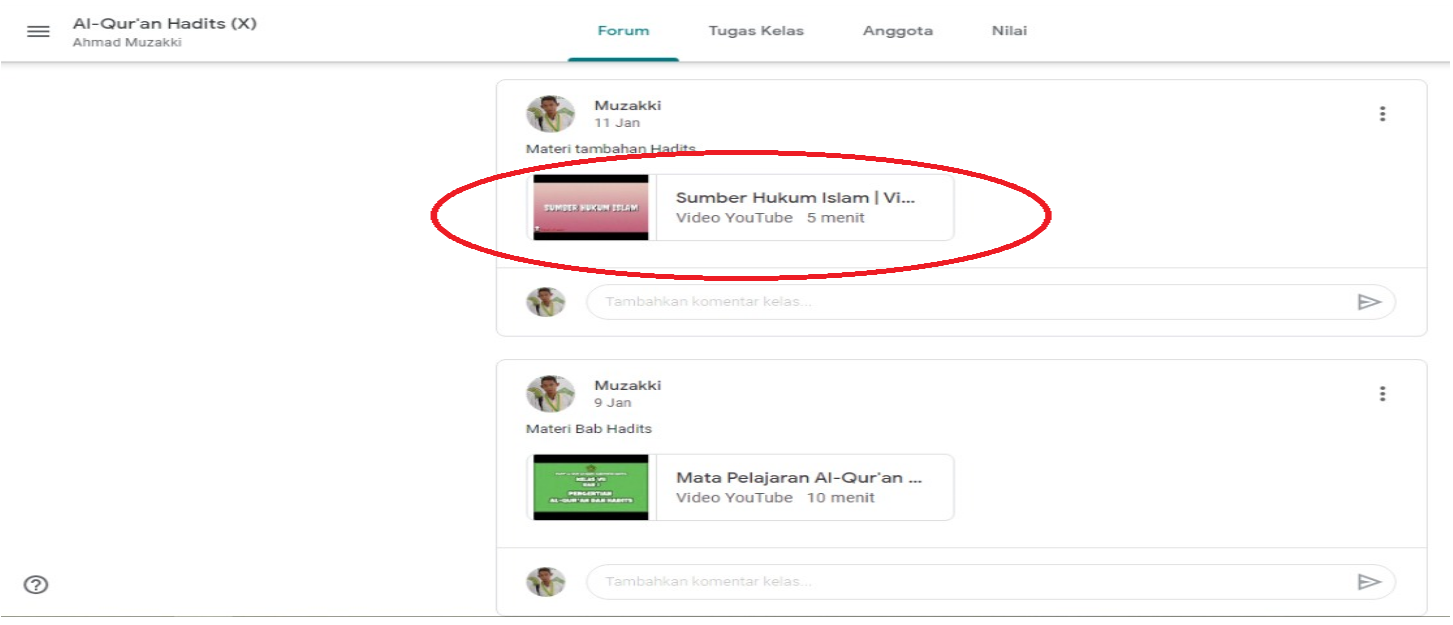

Gambar 7. Membagi link materi

\section{Membuat Pertanyaan (Create Question)}

Melalui fitur ini, guru bisa membuat dan memberikan pertanyaan kepada semua siswa atau siswa tetentu dalam bentuk pilihan ganda dan uraian, dengan masa tenggang tertentu yang dapat diatur sesuai keinginan guru. Fitur ini memudahkan guru dalam memberikan soal kepada siswa melaui menu google form.

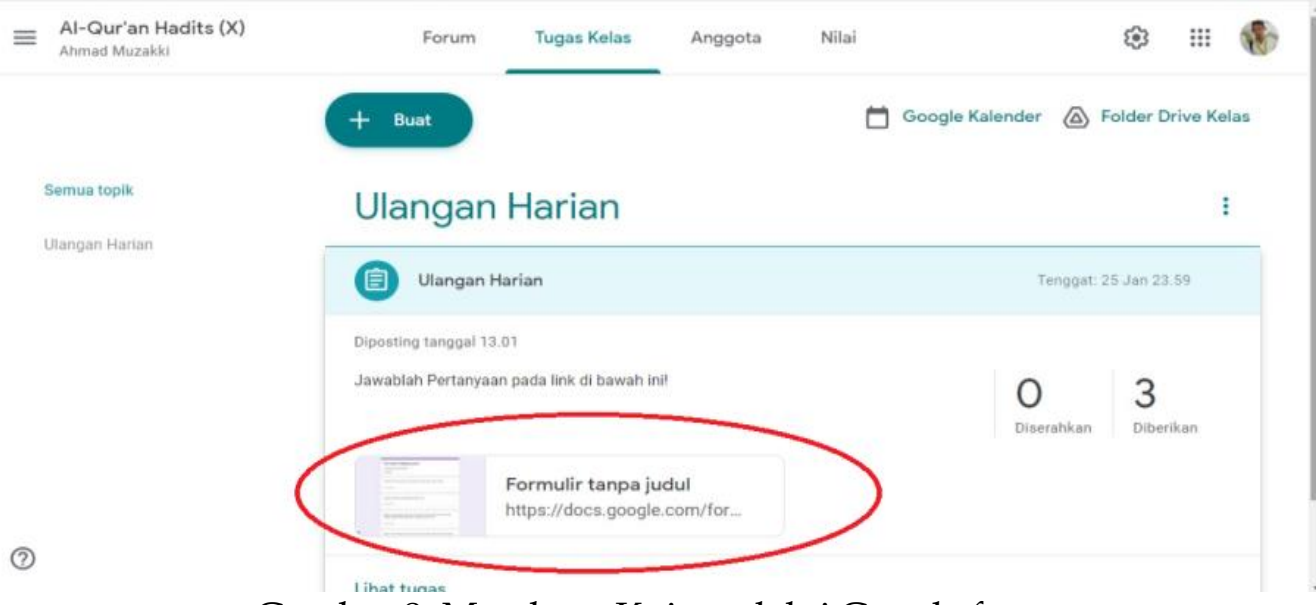

Gambar 8. Membuat Kuis melalui Google form

Menampilkan diatas menampilkan bagaimana guru membuat soal ulangan harian melalui menu google form. Adapun tampilan soal ulangan harian yang dibuat melalui menu google form adalah sebagai berikut :

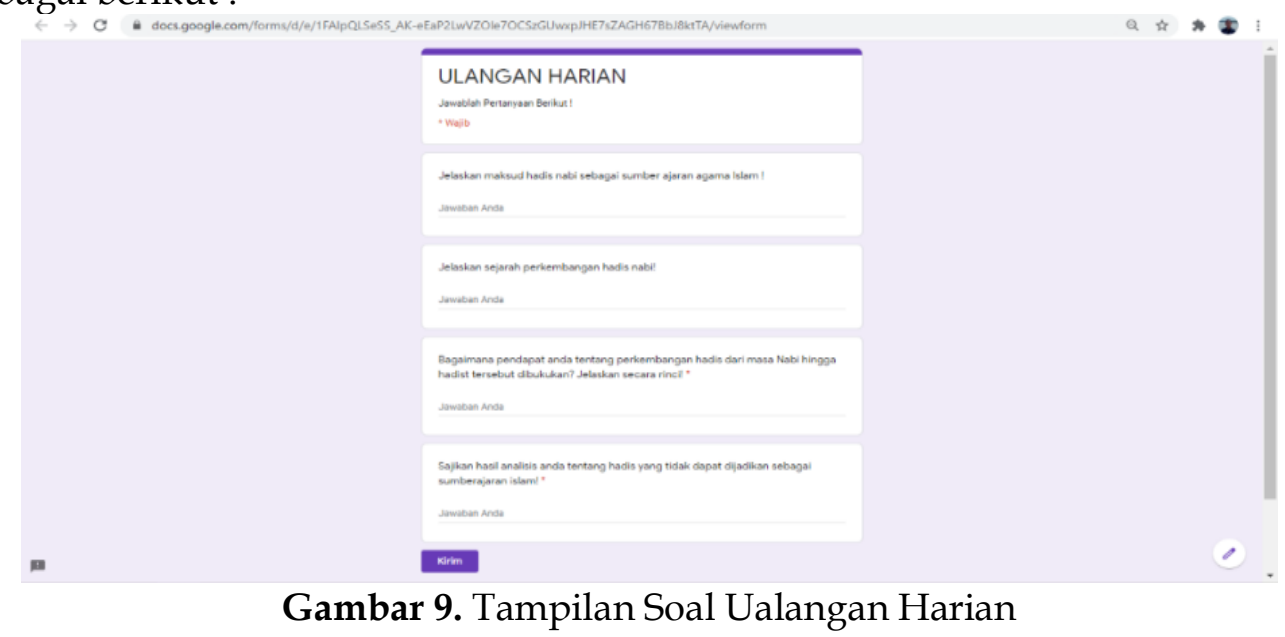


Dari tampilan diatas, siswa tidak perlu menulis soal dan jawaban, siswa bisa menjawab soal langsung di menu google form yang setelah itu bisa langsung dikirim.

\section{Penyimpana Satu Pintu (Terpusat)}

Menggunakan Google classroom seluruh materi dan hasil pembelajaran tersimpan terpusat di google drive secara cloud, yang mana dengan fitur ini tidak memakan storage computer ataupun smartphone. Apabila dalam menggunakan Google classroom akun yang digunakan adalag akun google suite, maka akan dapat layanan penyimpanan unlimited (tidak terbatas) yang tidak ditemukan ketika menggunakan akun google biasa, yang dibatasi sampai 15 giga byte saja. Seperti pada tampilan di bawah ini :

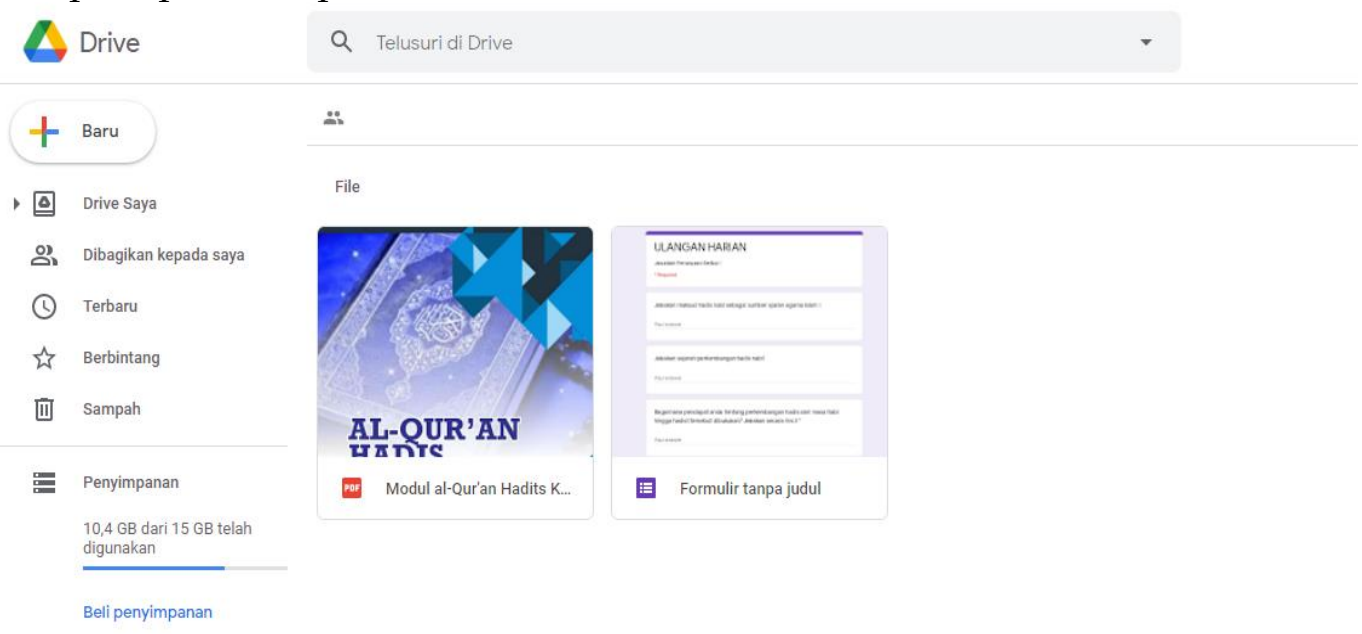

\section{Membuat Topik}

Gambar 10. Tampilan Google Drive

Fitur ini dapat digunakan guru untuk menentukan topic, jumlah pertemuan dan tema materi. Dengan fitur ini, maka manajemen pembelajaran di google classrrom akan berjalan dengan rapi dan teratur, karena sesuai dengan pertemuan dan tema yang dibahas. Selain itu, fitur topic ini juga memudahkan siswa dalam mengerjakan tugas yang diberikan oleh guru, siswa dapat mengetahui dengan mudah mana tugas yang dimaksudkan oleh guru di google classrrom.

Guru bisa membuat topik dengan cara klik menu (Buat), Seperti tampilan pada gambar di bawah ini :

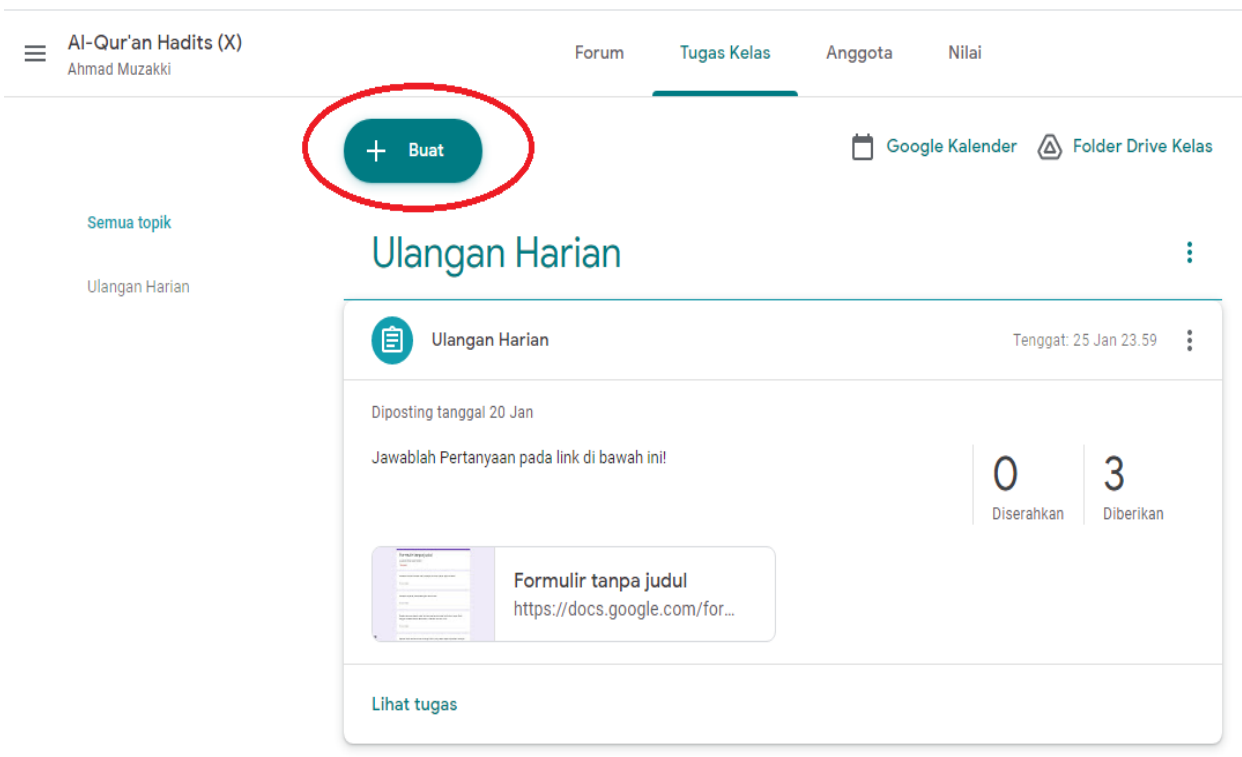

Gambar 11. Tampilan Membuat Topik Pelajaran 
Setelah memilih menu buat, selanjutnya bisa memilih menu topik dan membuat nama topik sesuai dengan keinginan guru, seperti pada tampilan di bawah ini:

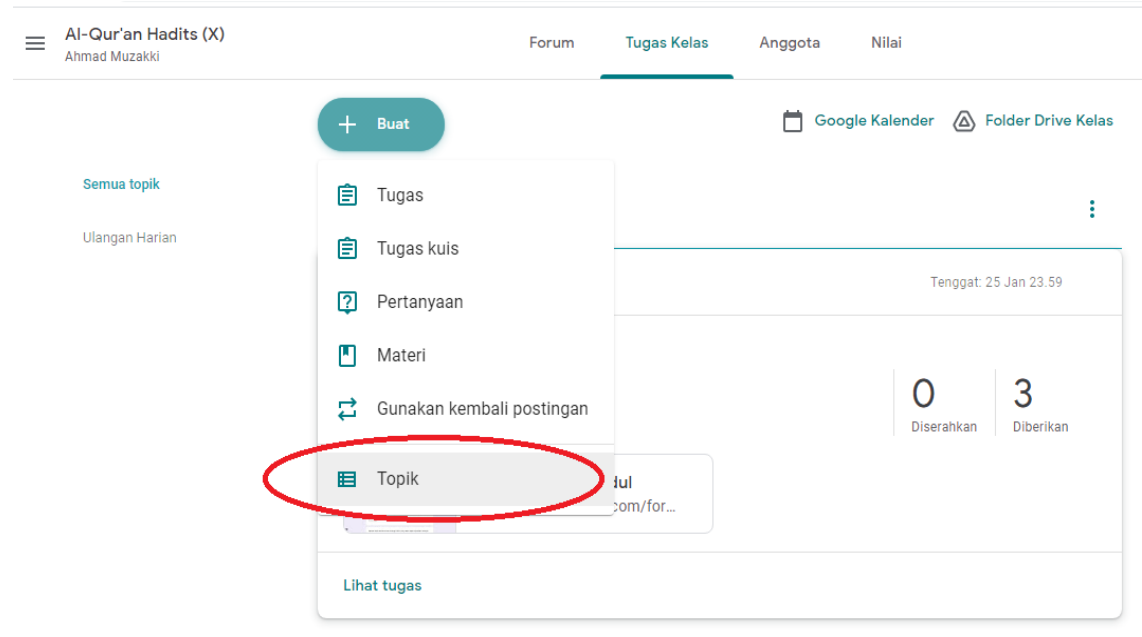

Gambar 12. Tampilan Membuat Topik Pelajaran

\section{Reuse Post}

Fitur ini digunakan untuk memposting ulang tugas atau materi yang sudah dikirim sebelumnya, guru dapat mengedit dengan menambahkan pertanyaan lalu dibagikan forum kelas tujuan. Salah satu keunggulan dari platform Google classroom adalah, guru dapat membuat beberapa kelas hanya dengan satu akun, dengan jumlah dan siswa yang berbeda, semacam membentuk rombel, hanya saja berbasis virtual. Guru dan siswa juga memiliki keleluasaan waktu untuk dapat mengakses materi dan soal, karena dapat diakses dimana saja dan kapan saja menggunakan perangkat computer atau smartphone yang terkoneksi jaringan internet.

Google Calendar

Fitur google calendar dirancang untuk memudahkan guru dalam menjadwal pelajaran sesuai dengan jumlah pertmuan, dalam fitur ini juga memudahkan siswa mulai dan sampai kapan pertemuan di kelas. Dalam menyusun jadwal kegiatan pembelajaran di google calendar, menyesuaikan kalender pendidikan.

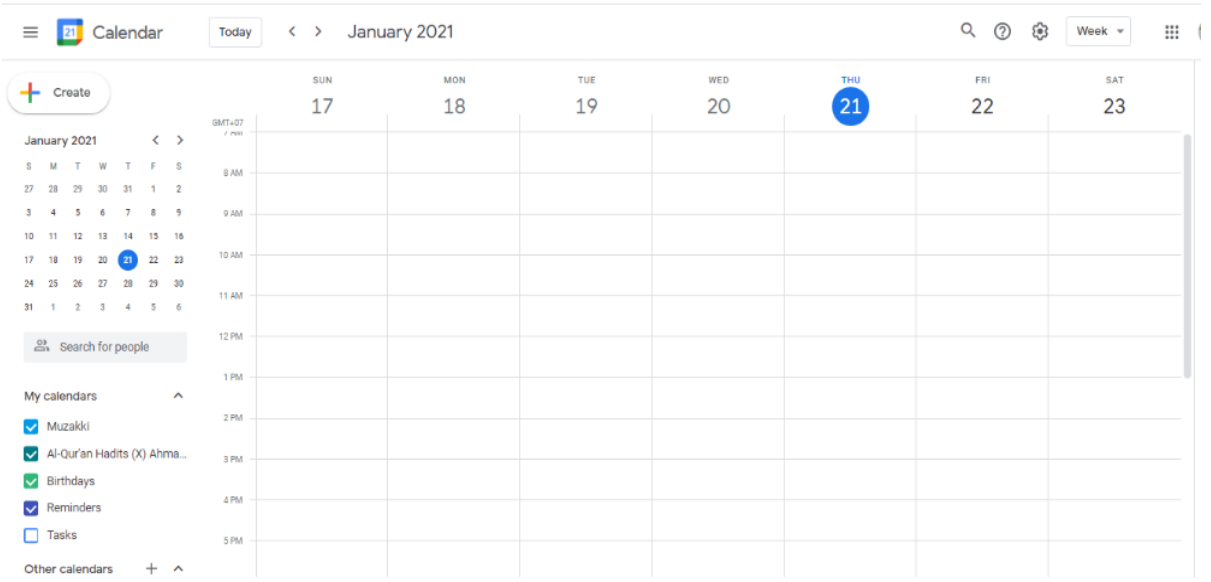

Gambar 13. google calendar

Google classroom ini termasuk aplikasi yang gratis, aplikasi ini dapat didownload di google playstore, apple store dan browser biasa, tanpa harus membeli. Tampilan awal pada halaman Google classroom ada tiga menu, yakni forum atau kelas, yang berguna untuk melihat notifikasi atau pemberitahuan akan adanya kiriman materi dari guru. Menu yang kedua yakni Tugas kelas, yang dapat memudahkan siswa untuk mengakses tugas dari guru, dan guru bisa 
memberikan tugas kepada siswa di dalam menu tugas siswa tersebut. Dan yang ketiga yakni menu Anggota, dari menu ini, guru dan siswa dapat mengetahui jumlah dan siapa saja anggota kelas dan gurunya. Setiap kelas bisa memiliki lebih dari satu guru, dan pada menu ini juga terdapat menu wali murid, berguna bagi wali murid untuk memantau aktifitas siswa dalam pembelajaran di Google classroom.

\section{Desain Pembelajaran Al-Qur'an Hadits Dengan Google classroom}

Proses pembelajaran Al-Qur'an hadits dengan google classroom dimulai dengan penjelasasan guru megenai rencana pembelajaran yang akan dilaksanakan. Setelah itu guru membagi siswa ke dalam kelompok sesuai dengan tingkatan kelas masing-masing. Pada setiap pertemuan, guru membagikan materi yang berupa modul, atau link video sesuai dengan materi yang akan diajarkan, yang kemudian digunakan siswa sebagai bahan ajar. Dalam pelaksanaan pembelajaran Al-Qur'an Hadits, modul yang diberikan guru, sesuai dengan kurikulum yang berlaku. Setelah itu siswa dapat mengakses dan mempelajari materi yang diberikan oleh guru dalam bentuk modul dan link video pembelajaran kepada siswa yang terdapat di forum kelas. Setelah pemberian materi, guru melakukan evaluasi kepada siswa terkait dengan materi yang diajarkan berupa soal yang diposting melalui menu tugas pada topik tertentu, serta dealine yang telah ditentukan. Kemudian siswa menjawab soal langsung melalui google form, yang terdapat di menu penugasan.

Desain pelaksanaan E-learning berbasis Google classroom pada mata pelajaran Al-Qur'an Hadits masih terkendala dengan pengetahuan siswa terhadap teknologi informasi. Tidak sedikit siswa dan guru yang masih awam dalam mengoperasikan penggunaan platform Google classroom ini. Diharapkan dengan adanya desain E-learning berbasis Google classroom ini bisa menambah pengetahuan guru dalam memanfaatkan platform Google classroom sebagai alternative pembelajaran jarak jauh. Selain itu, ketersediaan perangkat dan jaringan koneksi yang masih sulit, menjadi kendala dalam penggunaan Google classroom dalam pembelajaran.

\section{KESIMPULAN}

Pelaksanaan pembelajaran E-learning berbasis Google classroom pada mata pelajaran AlQur'an hadits memberikan kemudahan bagi guru, karena guru dapat menjalin komunikasi dengan siswa mengenai pemberian materi dan tugas yang disampaikan. Adapun desain pembelajaran e-learning berbasis google classrrom pada mata pelajaran Al-Qur'an Hadits meliputi : pembutana kelas virtual, lalu guru memasukkan siswa ke dalam kelas virtual sesuai dengan jenjang. Setelah itu, guru bisa memulai pembelajaran di kelas dengan mengatur jadwal pertemuan. Selanjutya guru bisa membagikan materi pembelajaran di forum kelas virtual dan penugasan kepada siswa sebagai bahan evaluasi. Seluruh kegiatan pembelajaran dapat dilakukan dengan memanfaatkan fitur-fitur yang terdapat di Google classroom juga lengkap untuk memnuhi kebutuhan proses pembelajaran, seperti: Assigment (penugasan), Komunikasi, Membuat Pertanyaan (Create Question), Penyimpana Satu Pintu (Terpusat), Fitur Orisinalitas, Fitur Material, Membuat Topik, Reuse Post, Google Calendar.

\section{UCAPAN TERIMA KASIH}

Terimakasih kepada bapak Dr. Abdulloh Hamid selaku dosen mata kuliah pengembangan media pembelajaran, yang telah membimbing saya untuk menulis hasil penelitian ini. Tidak lupa saya mengucapkan terimakasih kepada teman-teman yang senantiasa memberi semangat untuk menyelesaikan penelitian ini.

\section{DAFTAR PUSTAKA}

Ashadii, N. R., \& Suhaeb, S. (2020). Hubungan Pemanfaatan Google classroom dan Kemandirian terhadap Hasil Belajar Mahasiswa PTIK pada Masa Pandemi. Media Elektronik, 17(2), 4651. 
Budi Santoso. (2020). Penerapan E-learning Berbasis Google classroom Sebagai Media Pembelajaran Al-Islam dan Kemuhammadiyahan di Tengah Pandemi. Jurnal Al-Qiyam, 1(1), 100-108.

Daniati, Bambang Ismanto, D. I. L. (2020). Upaya Peningkatan Motivasi dan Hasil Belajar Mahasiswa dengan Penerapan Model Pembelajaran E-Learning Berbasis Google classroom pada Masa Pandemi Covid-19. Jurnal Kependidikan, 6(3), 601-608.

Dwining Bintarawati, Y. C. (2020). Implementasi Kelas Virtual Dengan Google classroom Untuk Meningkatkan Hasil Belajar. SPIN Jurnal Kimia Dan Pendidikan Kimia, 2(2), 177-190. https:// doi.org/10.20414/spin.v2i2.2573

Humaidi, H., \& Sain, M. (2020). Pengembangan Kreativitas Guru dalam Proses Pembelajaran. Al-Liqo: Jurnal Pendidikan Islam, 5(02), 146-160. https:/ / doi.org/10.46963/alliqo.v5i02.238

Maskar, S. W. (2019). Persepsi Peserta Didik Terhadap Metode Blended Learning dengan Google classroom. Jurnal Inovasi Matematika, 1(2), 110-121.

Niken Septantiningtyas. (2019). Pengembangan Desain Pembelajaran Pada Kelas Profesional PGMI Menggunakan Google classroom. Edudeena, 3(2), 101-107.

Rozak, A., \& Albantani, A. M. (2018). Desain Perkuliahan Bahasa Arab Melalui Google classroom. Arabiyat, 5(1), 83-102. 